\title{
Prediabetic risk factors among adolescents with obesity
}

\author{
Satriono, Ratna Dewi Artati", Dasril Daud, Ufy Trisnawati \\ From 7th APPES Biennial Scientific Meeting \\ Nusa Dua, Bali. 14-17 November 2012
}

\section{Background}

Childhood obesity has increased as a health problem worldwide and $\mathrm{WHO}$ have declared that obesity is a global epidemic problem which is needed to be managed promptly. In the last decades, prevalence of childhood obesity has raised dramatically. Childhood obesity may results in overweight and impose other health problems. It is also a risk factor for development of Type-2 Diabetes Mellitus (DM).

\section{Objective}

To determine prediabetic risk factors among adolescents with obesity.

\section{Methods}

The study was conducted as an observational study using cross sectional sectional and case control approaches. Data was collected from level I to III students of two selected Junior High Schools (SMP Katolik Rajawali and SMP Islam Athirah) in Makassar, Indonesia, started on August to October 2011. These students were adolescents with obesity and permissions to participate in the study were gained from their parents. Analysis were done using $\mathrm{X} 2$ test or Fisher Exact Test (significat value $\mathrm{p} \leq 0,05$ ) as well as logistic regression analysis.

\section{Results}

Data consisted of 114 sample, $75(65,8 \%)$ boys and 39 $(34,2 \%)$ girls. There were $35(76,1 \%)$ girls and $11(23,9 \%)$ boys with prediabetic. Logistic regression analysis showed that there were 3 factors asssociated with the occurence of prediabetic among adolescents with obesity, which were degree of obesity AOR 4,23 (95\% CI 1,92 to 10,77), history of breastfeeding AOR 3,9 (95\% CI

$1,55$ to 9,86$)$ and history of DM in the family AOR 6,48 (95\% CI 2,52 to 16,64$)$.

\section{Conclusion}

Degree of obesity, history of breast feeding and history of DM in the family are correlated with prediabetic occurence among adolescents with obesity.

Published: 3 October 2013

doi:10.1186/1687-9856-2013-S1-P91

Cite this article as: Satriono et al:: Prediabetic risk factors among adolescents with obesity. International Journal of Pediatric Endocrinology 2013 2013(Suppl 1):P91.

Submit your next manuscript to BioMed Central and take full advantage of:

- Convenient online submission

- Thorough peer review

- No space constraints or color figure charges

- Immediate publication on acceptance

- Inclusion in PubMed, CAS, Scopus and Google Scholar

- Research which is freely available for redistribution 